\title{
SF
}

524

- 52

N⿴

555

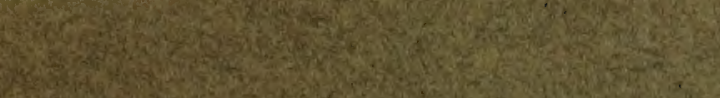

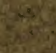
(1)
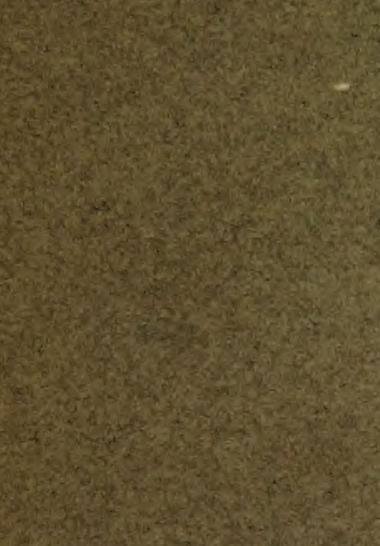


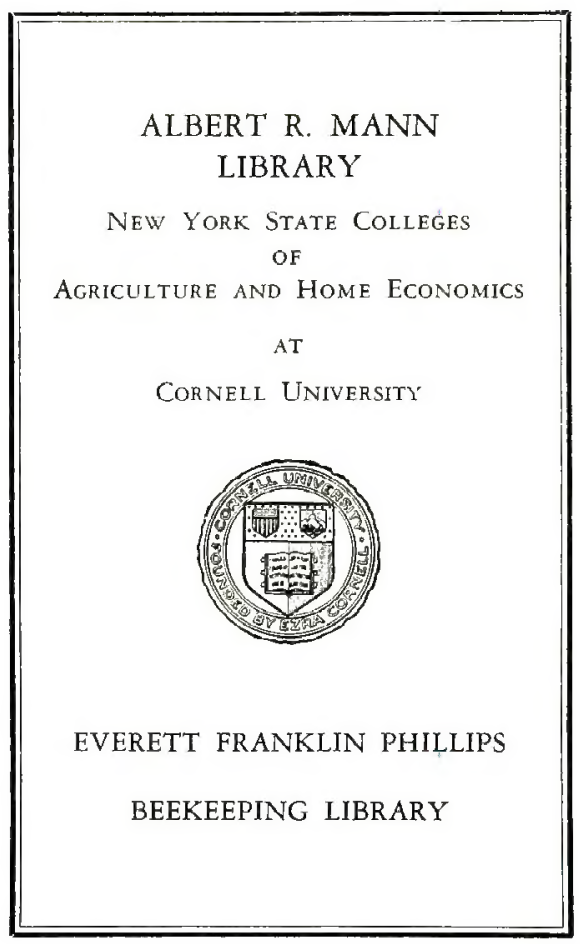




\section{THE BULLETIN}

OF THE

\section{NORTH CAROLINA}

\section{DEPARTMENT OF AGRICULTURE,}

RALEIGH.

Volume 29. $\quad$ JANUARY, $1908 . \quad$ Number 1.

\section{BEE-KEEPING IN NORTH CAROLINA.}

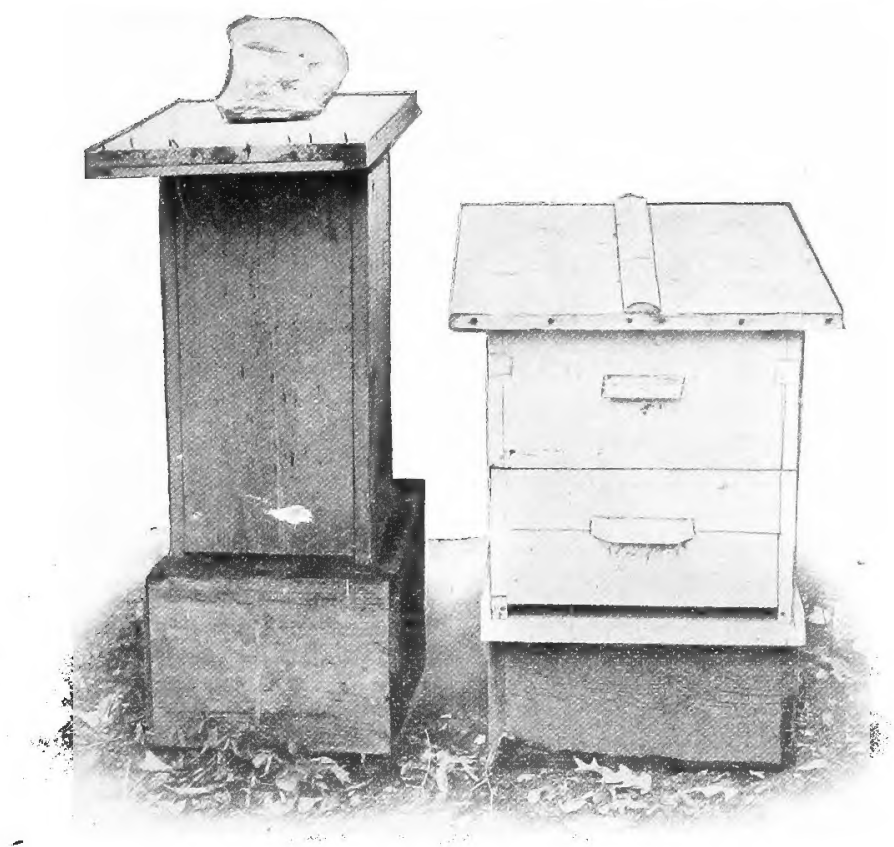

The crude, plain box hive, as shown at the left, produces each year an average of $271 / 3$ pounds of honey, worth $\$ 2.60$.

The frame hive with super, shown at the right, produces each year an average of $37 / 2$ pounds of honey, worth \$4.13. Therefore, USE FRAME HIVES. (Photo by Prof. Hutt). (See page 18).

PUBLISHED MONTHLY AND SEN'T FREE TO CITIZENS ON APPLICATION. 


\section{STATE BOARD OF AGRICULTURE.}

S. L. Patterson, Commissioner, ex officio Chairman, Raleigh.

J. J. LAUghinghouse......... Greenville ............... First District.

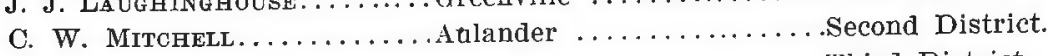

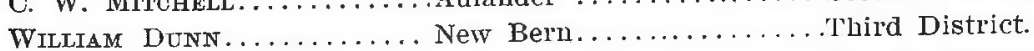

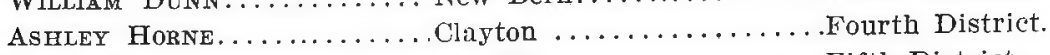

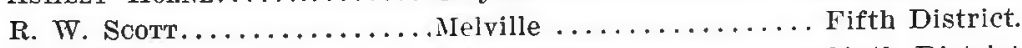

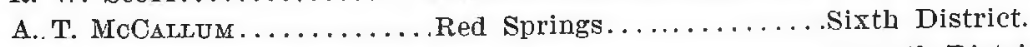

J. P. McRae............. Laurinburg . . . . . . . . . . Seventh District.

R. L. Doughton............ Laurel Springs.......... Eighth District.

W. A. Graham ........... Nachpelah ......... Ninth District.

A. Cannon................ Horse Shoe.......... Tenth District.

\section{OFFICERS AND STAFF.}

S. L. Patterson . . . . . . . . . . . . . . Commissioner.

T. I. BRUNER . . . . . . . . . . . . . . . . . Secretary.

B. IV. Kilgone................ State Chemist, Field Crops.

Tait Butler............... Veterinarian, Animal Husbandry.

FrankLtN Sherman, Jr............... Entomologist.

W. N. Hutr. . . . . . . . . . . . . . . . . . Horticulturist.

H. H. Brimley..........................

T. B. PARKER. . . . . . . . . . . . . . Demonstration Work.

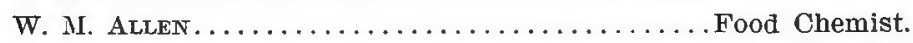

J. M. PiCkel. ................... Assistant Chemist.

C. D. HARris. Assistant Chemist and Microscopist, Stock Feeds.

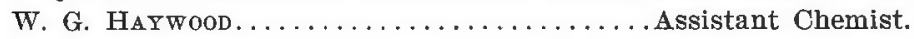

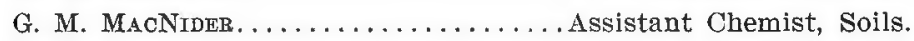

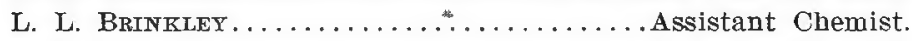

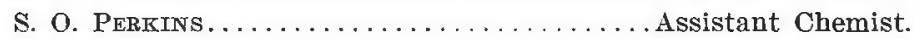

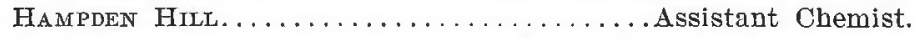

S. C. ClaPp................. Nursery and Orchard Inspector.

R. W. ScotT, JR., Superintendent Edgecombe Test Farm, Rocky Mount, N. C.

F. T. Meacham, Superintendent Iredell Test Farm, Statesville, N. C.

John H. Jefreries, Superintendent Pender Test Farm, Willard, N. C.

R. W. Coldett, Superintendent Transylvania Test Farm, Blantyre, N. C.

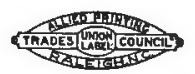




\section{CONTENTS.}

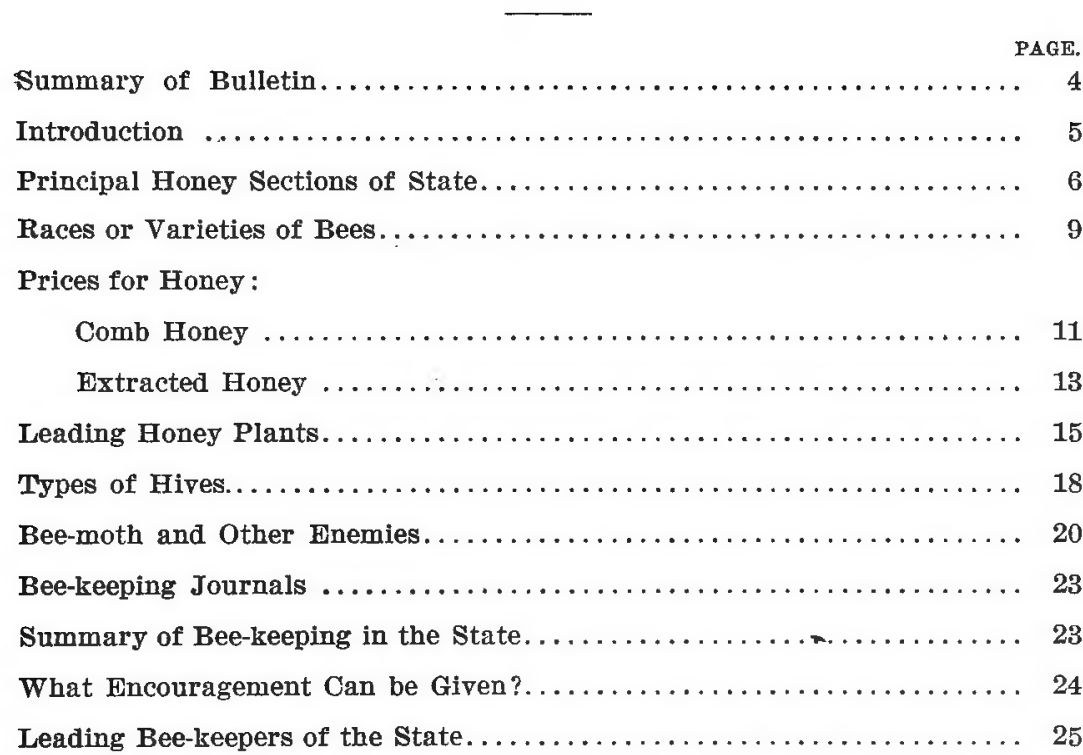




\section{SUMMARY.}

THE MORE IMPORTANT FACTS BROUGHT OUT IN THIS BULlETIN ARE AS FOLLOWS: FroM A CAREFUL STUDY OF DETAILED REPORTS FBOM 360 BEE-KEEPERS OWNING A TOTAL OF OVER 10,400 COLONIES, WE FIND THAT ON THE WHOLE, THE BEE-KEEPING INDUSTRY IS MUCH WORE LAGELY DEVELOPED IN THE EASTERN THAN IN THE MIDDLE OR WESTERN SECTIONS OF THE STATE, THOUGH THE ACTUAL YIELD OF HONEY SEems to be about the same tN all Sections. The Italian bees are DeCIDEDLY SUPERIOR TO EITHER THE HYBRIDS OR THE BLACKS, BOTH AS TO HONEY PRODUCED AND AS TO RESISTANCE TO BEE-MOTH AND OTHER ENEMIES, BUT (IN THE EASTERN PART OF THE STATE ESPECIALlY) IT IS ÁteESSARY TO FREQUENTLY IMPORT FERTILIZED QUEENS TO KEEP THE STOCK PURE. THERE ARE THREE HONETPLANTS WHICH ARE FAR AHEAD OF aLL OThers, THESE BeiNg: 1. SoURWOOD; 2. Poplar or Tulip-tree; 3. Clovers of all vareities. Sourwood, where it OCCURS, OUTRANKS ALL OTHER PLANTS IN QUALITY AND QUANTITY OF HONEY PRODUCED, AND ALSO COMMANDS THE BEST PRICE PER POUND. THOSE VHO DEAL IN LIQUID HONEY WOULD DO WELL TO USE MODERN EXTRACTORS RATHER THAN TO "Squeeze" The honey out by hand. The modern hives, Made With movable FRAMES, YIELD MUCH MORE HONEY, WHICH ALSO SELLS AT A HIGHER PRICE, THAN EITHER THE CRUDE BOX HIVES OR HOLLOW-LOG "GUNS." BEE-MOTH IS ESPECIALLY DESTRUCTIVE IN LOQ "GUMIS," BUT MUCH IESS TROUBLESOME IN FRAME HIVES. THE DISEASE KNOWN AS FOUL-BROOD HAS BEEN TWICE REPORTED BUT NOT CONFIRMED, AND IT IS OF HIGHEST IMPORTANCE THAT OUR BEE-KEEPERS SHOULD WATCH FOR THIS DISEASE AND REPORT THE FACTS IF FOUND. THERE IS SOME SEN-

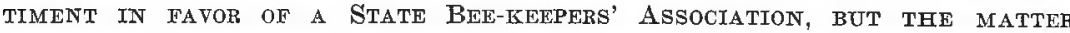
SHOULD BE VERY CAREFULLY CONSIDERED BEFORE ATTEMPTING TO ORGANIZE. A LIST OF THE LEADING BEE-KeEPERS OF THE STATE IS GIVEN IN THE LATTER PART OF THE Bulletin. 


\title{
BEE-KEEPING IN NORTH GAROLINA.
}

\section{A STUDY OF SOME STATISTICS ON THE INDUSTRY, WITH SUGGESTIONS AND CONCLUSIONS.}

\author{
By Franklin Sherman, Jr., Entomologist.
}

INTRODUCTION.

Bee-keeping is an old industry in this State-so old that it has been allowed in some cases to settle into ruts, which are not only unprofitable, but hard to get out of. There is perhaps no other industry in the State of equal importance and with equal opportunities for development which is so disorganized, so disconnected and suffering so badly from lack of careful attention and better methods as is the bee-keeping business. We make this remark as applying to the State as a whole, for there are some individuals who are conducting their apiaries along modern and profitable lines.

There is no State organization in which our bee-keepers meet to exchange views; there is no system of inspection by which the apiaries may be brought to a higher standard; the bee-keeping magazines have but a limited circulation with us, and there is nowhere in the State a practical bee-keeper whose special duty it is to encourage or protect this industry.

In order to see if we could reach any of the fundamental facts underlying this industry in the State, the writer--though not an actual bee-keeper-began an inquiry into the industry in the summer of 1905 , which has been continued (with interruptions) to the present time. A carefully prepared sheet of questions was sent out, and all data received in reply have been carefully recorded. We have left out of account any who have less than ten colonies of bees, so that the data which we have is from actual commercial bee-keepers. We have on record replies from about 360 persons, representing a total of 10,450 colonies, located in seventy-eight counties-an average of 134 colonies for each county heard from, or an average of nearly 108 colonies for each and every county in the entire State. We feel that with such an amount of data we are warranted in deducting some conclusions regarding the industry in the State as a whole.

Of course we have not heard from anywhere near all of the commercial bee-keepers. We know positively of several from whom we have not heard. Doubtless some of the counties from which we have 
heard little or nothing, have as well-developed a honey industry as any. For instance, in Madison County, on the west, we have record of 23 bee-keepers, with a total of 646 hives, while in the neighboring county of Mitchell, which is presumably just as well fitted for the industry and with perhaps as many colonies, we have record of only one man, who has 10 colonies. In the east we find Martin County with eight bee-keepers on record, owning a total of 716 colonies (average, 891/2 each), while the neighboring county of Pitt has only one bee-keeper, with 15 colonies, on our records. We mention these instances to show that, while we have been successful in collecting much data from various parts of the State, it is probably by no means complete for all or, indeed, for any of the counties.

The list of questions which we sent out is as follows:

1. How many colonies of bees have you?

2. What race or variety of bees do you keep?

3 . What is your average honey yield per hive each year?

4. What are your highest and lowest prices for boney per pound?

5. What are your principal honey plants?

6. What plant, in your opinion, yields the best quality of boney?

7. What plant, in your opinion, yields the largest quantity of honey?

8. What kind of gum, box or bive do you use?

9. Are your bees troubled with Foul-brood, Bee-moth, Paralysis, or other enemies?

10. What bee-keeping journals, if any, do you take?

This Bulutetin is based entirely on the answers to these questions, sent, as we have said, by 360 bee-keepers, representing 10,450 colonies of bees. The writer makes no pretense to any knowledge of beekeeping, except such as he has learned from these cuntributors. But the inquiry is sufficiently broad and has been responded to sufficiently well, so that many facts and deductions can be positively stated, after full consideration of them all.

The author desires to acknowledge valuable assistance rendered by the numerous bee-keepers, and wishes also to express special thanks to Prof. W. N. Hutt for taking the several photographs with which THE Buldetin is illustrated; to Mr. T. B. Parker for valuable suggestions in preparing the manuscript, and to Mr. Burton N. Gates, Expert in Apiculture, United States Department of Agriculture, for correcting some technical errors and for suggestions.

\section{PRINCIPAL HONEY SECTIONS OF THE STATE.}

Probably the first question that would naturally arise is, Which is the leading bee-keeping county? Or, Which section of the State is in the lead? This is not easy to answer, and several different conclusions may be reached, according to the point of view. Martin County leads in the total number of colonies on record; Washington leads in the average number of colonies owned by each bee-keeper, while 


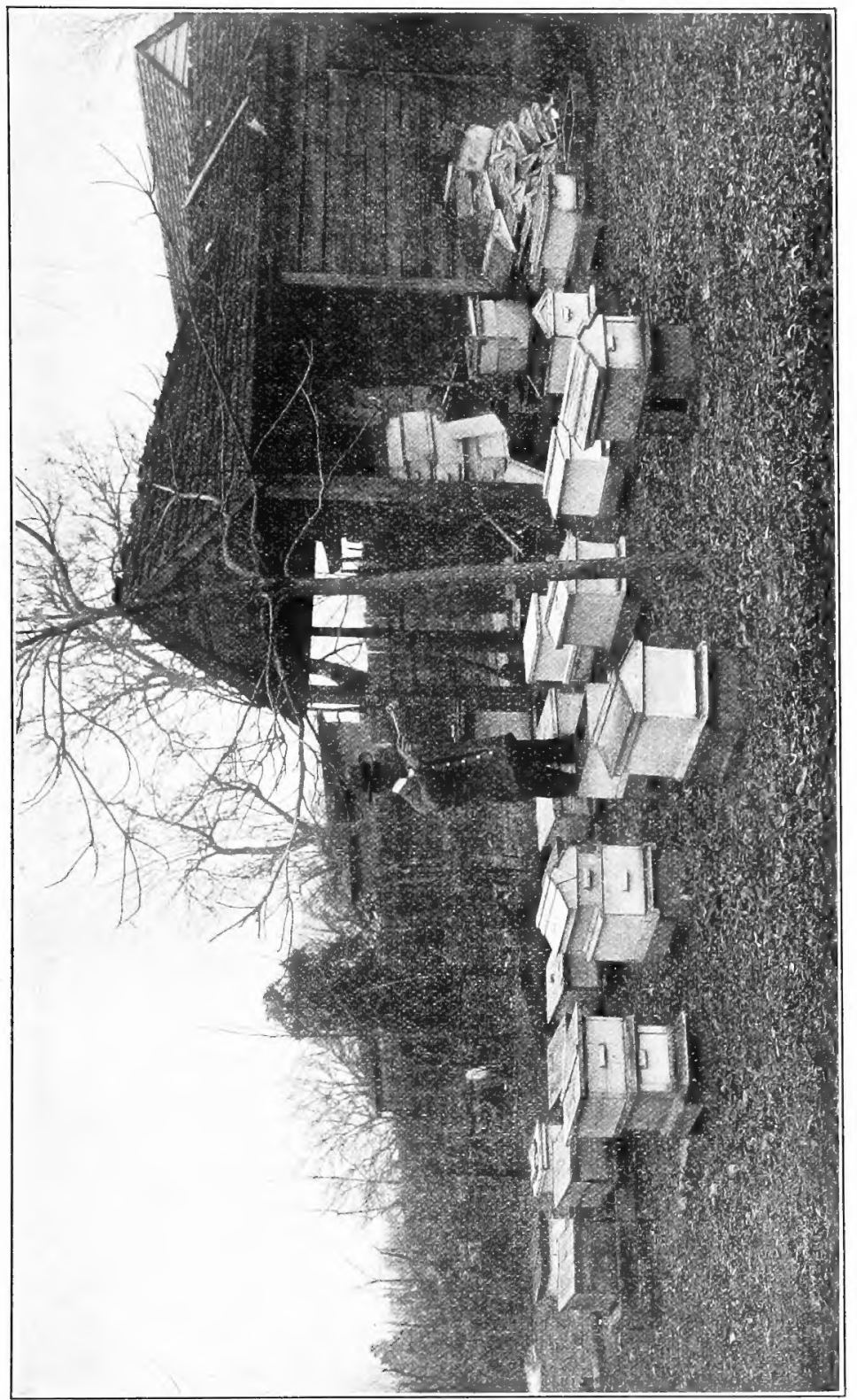

空 
Madison leads in the total number of bee-keepers. Taking into account only those counties which have on record 250 colonies or over, we present the following table:

LEADING BEE-KEEPING COUNTIES.

\begin{tabular}{|c|c|c|c|c|}
\hline County. & Section of State. & $\begin{array}{c}\text { Total Colo- } \\
\text { nies of Bees } \\
\text { Reported. }\end{array}$ & $\begin{array}{c}\text { Number of } \\
\text { Bee-keepers } \\
\text { Reporting. }\end{array}$ & $\begin{array}{c}\text { Average } \\
\text { Number } \\
\text { Colonies Per } \\
\text { Bee-keeper. }\end{array}$ \\
\hline Beaufort --. & East & 421 & 12 & 35 \\
\hline Bladen -..- & East & 353 & 11 & 32 \\
\hline Duplin---... & East_.-_ & 445 & 10 & $441 / 2$ \\
\hline Iredell -....-.. & Central-_- & 325 & 13 & 25 \\
\hline Madison -..-- & West - . & 646 & 23 & 28 \\
\hline Martin-........ & East ............ & 716 & 8 & $891 / 2$ \\
\hline McDowell ---... & Central & 262 & 11 & 24 \\
\hline Onslow -..- & East & 484 & 13 & 37 \\
\hline Robeson & East & 374 & 14 & 27 \\
\hline Washing ton - & East..... & 300 & 3 & 100 \\
\hline
\end{tabular}

We see, therefore, that, so far as our records go, they show decidedly that at present the leading honey-producing region of the State is the southeastern and eastern parts, which is explained by the fact that there are in those sections thousands of acres of swamp land which never have been and perhaps never will be cultivated, but in which a number of excellent honey plants (gallberry, huckleberry, etc.) grow to perfection. All this section may, therefore, be considered as one (the eastern) region. Leaving this region, we pass across a wide belt of country in which there are no specially favored bee-keeping sections, until we get to the upper piedmont and mountain counties, where the mixed forests, wild clovers, and best of all, the famous sourwood flourish. Here the opportunities for bee-keeping are only limited by the clearing of the land for crops which are not honey producers. So far as the writer is able to judge, a skillful bee-keeper will do about as well in one of these sections as the other, with this difference: that in the piedmont and western counties, on account of colder climate, more care is needed in wintering the bees, and the favorable locations, where the best plants grow, are somewhat more restricted than in the east. To offset this disadvantage, it may be said that all bee-keepers, wherever the sourwood grows, rank it first among the honey plants, and this queen of honey producers is most abundant in the upper piedmont and lower mountain sections.

In this connection it is proper to attempt to determine where the honey yield is greatest. To attempt this for each individual county 
could serve no real purpose, since in many cases the difference would be accounted for by other conditions than that of the honey flow. But if we take three typical counties, representing, respectively, the eastern, the piedmont and the western sections, we should derive some sound conclusions, since the honey plants in these three sections are decidedly different, and such differences in returns as exist are likely due to the honey flow. For this calculation we have taken the counties of Onslow, Iredell and Madison. Eliminating a number of reports which, for various reasons, cannot be used in this estimate, we construct the following table from those that are available, and, though it is based on too few reports to be absolutely conclusive, it shows about what we would judge to be the true comparison:

HONEY YIELD IN DIFFLRENT SECTIONS.

\begin{tabular}{|c|c|c|c|}
\hline County. & $\begin{array}{l}\text { Location } \\
\text { in State. }\end{array}$ & $\begin{array}{c}\text { Number of } \\
\text { Reports. }\end{array}$ & $\begin{array}{c}\text { Average Yield } \\
\text { Per Hive. }\end{array}$ \\
\hline Onslow & East----... & ---4 & $361 / 2$ pounds. \\
\hline Iredell - & Piedmont & - 5 & $421 / 2$ pounds. \\
\hline Madison-_-_-_- & West -.... & --_--_-17--- & 38 pounds. \\
\hline
\end{tabular}

RACES OR VARIETIES OF BEES.

The Italian (in its various strains) is the leading bee for this State. To determine the relative desirability of the kinds, we must take into account the honey yield which each produces. The leading varieties are: Italians, Blacks, and Hybrids (or mixed), which are derived from the crossing of Italians with the Blacks. About 100 of our bee-keepers gave no estimate of their yearly yield per colony, and in other cases we have been obliged to make averages between the high and low yields which the same bee-keeper often reports. It is only the most careful bee-keepers who actually keep accurate record of the yield.

One person who keeps Carnolians reports an average yield of 64 pounds per hive; three who have Italians crossed with Carnolians report an average yield of 30 pounds per hive; but in both these instances the number reporting is too small to warrant any conclusions as to the merits of these breeds. It is only when we have a large number of reports that we can expect the general average to give an accurate idea of the true conditions. For the Italians, Blacks, and Hybrids we have a sufficient number of reports so that we can feel some confidence in the averages which they show. We have reports from 89 persons who keep Italians, 88 who keep the common Blacks, and 83 who have the Hybrid bees. A number give the yield 
in gallons (extracted honey), but the majority report it in pounds (comb honey). Bringing all these reports together and averaging them, we find the following:

HONEY YIELD FROM DIFFERENT RACES OF BEES.

\begin{tabular}{|c|c|c|c|c|c|}
\hline \multirow[b]{2}{*}{ Race of Bees. } & \multirow{2}{*}{$\begin{array}{c}\text { Total } \\
\text { Bee-keepers } \\
\text { Reporting. }\end{array}$} & \multicolumn{2}{|c|}{ Yield in Gallons. } & \multicolumn{2}{|c|}{ Yield in Pounds. } \\
\hline & & $\begin{array}{l}\text { Number } \\
\text { Reporting. }\end{array}$ & $\begin{array}{l}\text { Average } \\
\text { Yield } \\
\text { Per Hive. }\end{array}$ & $\begin{array}{l}\text { Number } \\
\text { Reporting. }\end{array}$ & $\begin{array}{c}\text { Average } \\
\text { Yield } \\
\text { Per Hive. }\end{array}$ \\
\hline Italians -.--. & 89 & $4^{\prime}$ & 4 gallons. & 85 & $402 / 3$ pounds. \\
\hline Hybrids & 83 & 11 & 4 gallons. & 72 & $34 \frac{1}{2}$ pounds. \\
\hline Blacks --1- & 88 & 20 & $31 \frac{1}{2}$ gallons. & 68 & $261 / 3$ pounds. \\
\hline
\end{tabular}

From the above we see that the Italians lead the Hybrids by an average of 6 pounds per hive each season, while the Hybrids in turn lead the Blacks by an average of 8 pounds. This puts the Italians 14 pounds ahead of the Blacks in average yield per hive each season. In these cases, also, there is a sufficient number reporting to give reliability, and they demonstrate the advantage of the Italians over the others. As regards gallons of extracted honey, there are too few reporting to give so reliable a comparison, but here we find the Italians and Hybrids standing together with an average yield of 4 gallons, while the Blacks follow at $31 / 2$ gallons. It is to be noted that only four of the 89 persons who keep Italians report the yield in gallons, eleven of those with Hybrids report in gallons, and twenty of those who keep Blacks give the yield in gallons. The Italians have an advantage in the care given them, for most of those keeping Italians use some improved type of hive, while fully half of those who keep the Blacks keep them in old hollow-log "gums." In the east, where, as already mentioned, there are interminable swamps and forests of fine bee pasturage, and where there are countless swarms of wild bees in the forests, we find the Black bees predominating in the apiaries, and this largely accounts for the low average yield. Considering, now, only the larger bee-keepers, those having fifty or more colonies, we find:

DISTRIBUTION OF ITALIAN, BLACK AND HYBRID BEES IN APIARIES OF FIFTY OR MORE COLONIES.

\begin{tabular}{|l|c|c|c|}
\hline Section of State. & $\begin{array}{c}\text { Number } \\
\text { Keeping } \\
\text { Italians. }\end{array}$ & $\begin{array}{c}\text { Number } \\
\text { Keeping } \\
\text { Hybrids. }\end{array}$ & $\begin{array}{c}\text { Number } \\
\text { Keeping } \\
\text { Blacks. }\end{array}$ \\
\hline East - & & & \\
\hline Piedmont & & & \\
West_- & & & \\
\hline
\end{tabular}


From this we see that in the east the tendency is to make use of the wild Black bee as found in the native forest, or, even when Italians are introduced, they mingle with the wild Black, producing a Hybrid. It seems to be much more difficult to keep the Italians pure in the eastern section, necessitating frequent introduction of fertilized Italian queens from other apiaries. In the middle and the mountain sections there seems to be less diffeulty along this line. In the region where the sourwood abounds the Italian is the decided favorite, for of the nine large bee-keepers on record in this (the piedmont) region six keep the pure Italians, while the other three have Hybrids in which there is Italian blood.

Thus we see, taking a view of the matter from all sides, that the Italian is in the lead throughout the State as a whole, though outstripped in numbers by the Blacks in the east. The Italians also have a decided lead in the yield of honey, and are especially preferred in the sections where the finest quality of honey is made. When a bee-keeper gets to the point of working up a fancy trade in highpriced honey, he is likely to abandon the Black bees and log "gums" and stock up with pure Italians in modern frame hives, in which the marketable honey is stored in pound sections, or in frames from which it can be easily extracted. The main objection to this lies in the difficulty of keeping the stock pure, and the expense of continually introducing new queens; but, in view of the higher average yield from the Italians, as shown in these pages, it would seem that they more than compensate for this trouble and expense.

PRICES FOR HONEY.

Comb Honey.-There is, of course, a wide range in the prices paid for honey, depending upon the demand and supply, and also depending upon the distance to the larger towns, the source from which the honey is derived, its color, etc. The prices mentioned for comb honey (with 215 persons reporting) range from 5 to 20 cents per pound, the bulk being sold, however, at from 10 to 15 cents. Averaging all the reports for 215 persons, we get a fraction less than 12 cents as the average price for comb honey throughout the State as a whole. An effort to determine in which section of the State the highest prices prevail is only partially successful, owing to the fact that we have not enough reports from representative counties in all sections to warrant conclusions. Six persons reporting from Onslow show an average price of exactly 12 cents per pound; nine from Iredell report an average of a fraction more than 12 cents, while twenty reporting from Madison show an average of a fraction less than 13 cents per pound. This puts the three sections (east, central, and west) on practically the same basis, so far as price is concerned. But here again we find the sourwood showing the superiority of its 
honey, when it is abundant enough to give a fair yield. This plant grows well in the Brushy Mountains, in northern Iredell, in Alexander and in southern Wilkes counties; and the remarks of two of the bee-keepers of this region with regard to honey prices are significant. One says: "Dark honey, 10 to 12 cents; sourwood, 15 to 20 cents"; the other reports: "Red honey, 10 cents; sourwood, 20 cents." (The sourwood produces a light or "white" honey). While the general

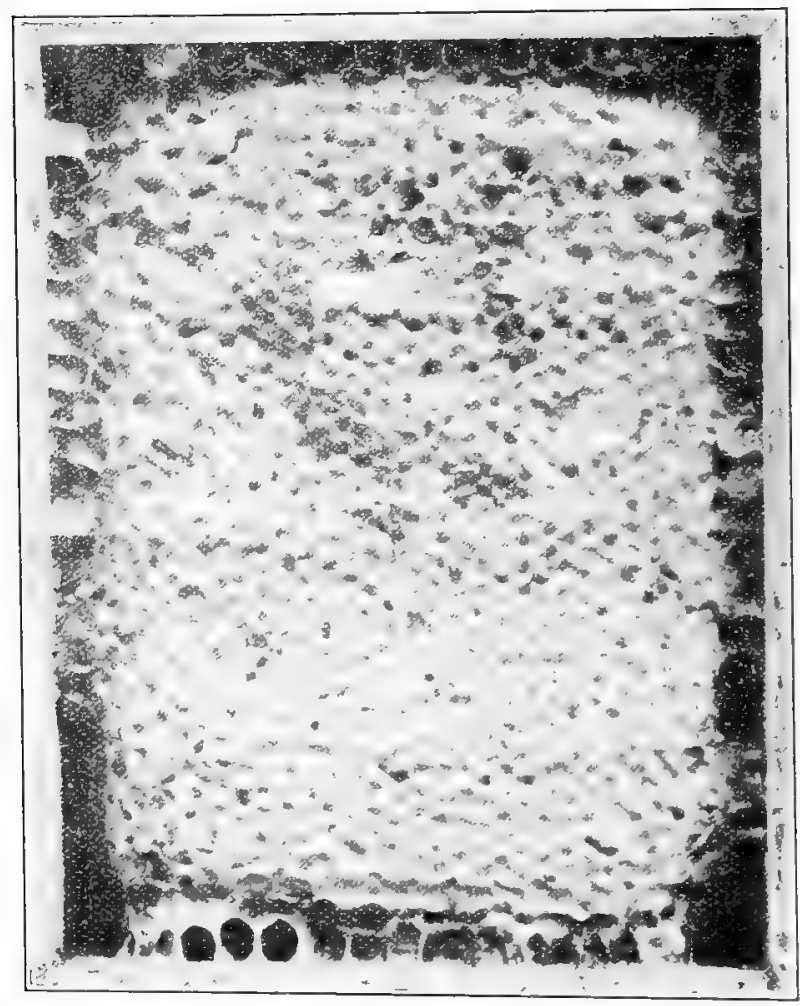

FIG. 2.-A well-filled pound section, usually retailing at 18 to 20 cents. About three-fourths actual size. (Photo by Prof. Hutt).

average of prices in the sourwood section may not be above that of other sections, yet those who take full advantage of the flow from this plant realize a better price from its honey than from any other. Some bee-keepers make a practice of taking away all surplus when the sourwood comes on, and taking it again at the close of the sourwood season, so as to have that honey pure for the fancy trade at highest prices. 
In some instances the price for honey seems to be very uniform for a whole county. For instance, in Johnston County, out of seven reporting, five mention only one figure-10 cents per pound-while of the other two, one gives his usual prices as from 10 to $121 / 2$ cents, and the other gives 10 to 15 cents.

Extracted Honey.-The majority of our bee-keepers sell the comb honey, but in the east a great deal is extracted (often by the crudest methods) and sold. As none of our questions related directly to the extracted honey, and as even the question of price was based on comb honey, we have only very incomplete data as to the extent that extracting is practiced and the prices secured for the extracted honey, and no data whatever as to the prices secured for the wax. Most of those who reported on extracted honey are in the east, particularly in Bladen, Onslow, Duplin and neighboring counties. From these, fifteen persons report an average price of $521 / 3$ cents per gallon for extracted honey. This is a low price, and is apparently the result of several causes. The methods of extracting are often crude and cannot fail to reduce the price, resulting as they do in much sediment and foreign matter being left in the honey. The process known as "squeezing" consists simply in forcing the honey from the comb by hand into an open tub or trough, and, added to the unpleasant thought that the honey has all run over the hands and fingers of some one, is the certain fact that, while this is going on, more or less dust, fine particles of trash, etc., are blown in. Then, again, when old hollow-log "gums" or plain box hives are used, there is not that clear and certain distinction between the brood, bee-bread, and surplus honey that there is when modern hives are used; consequently, "squeezed" honey may contain bits of comb, bee-bread and an occasional wing, leg, head or body of a bee-all of which tends to depress the price. Modern extractors, by which the honey is cleanly and thoroughly removed from the combs, are not nearly so commonly used as they should be.

It seems certain to the writer that in our eastern section, where there is such endless bee pasturage, either comb or extracted honey should be capable of very profitable production, and some do produce both profitably; but surely something could be gained by using hives in which the honey is stored in frames, which then fit into a regular extractor, from which the honey is quickly and thoroughly extracted without waste, at the same time keeping it pure and appetizing. Some improvement in the methods at present employed is very desirable.

There is another point to be remembered in regard to the sale of comb and extracted honey. Recent investigations, both in this State and in other States, show that there is on the markets a great amount of adulterated and imitation food products of all sorts. Extracted honey can be adulterated, and at least one case has been discovered by 
Mr. W. M. Allen, Food Chemist in our Department, where a material supposed to be extracted honey was found, when analyzed, to consist entirely of syrups, flavors, etc., which had been derived from other sources. It was purely an imitation honey, yet floating about in this

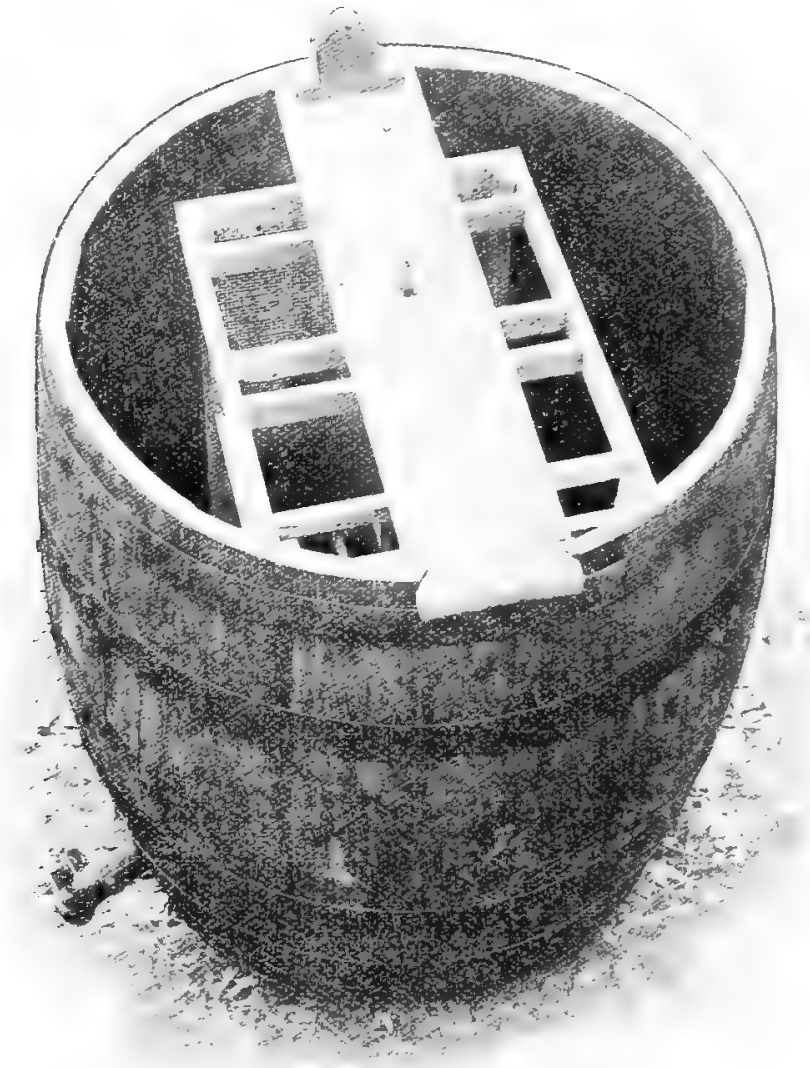

Fic. 3.-A home-made extractor. The frames filled with honey, after being uncapped with - a knife, are placed in this machine and the honey thrown out by rapid turning with a crank. The honey is then drawn out by means of the spigot at bottom of the extractor. (Photo by Prof. Hutt).

material was a leg of a bee, $\mathrm{rr}^{\mathrm{r}}$ a wing, or a tiny bit of comb, to make the deception complete! The honest bee-keeper who sells extracted honey must sell in competition with these fraudulent and adulterated products, and he is thereby put to a disadvantage, and accordingly 
gets a lower price, since everything that is sold under the name of extracted honey falls under suspicion unless the bee-keeper has a fixed trade and has the full confidence of his customers. On the other hand, comb honey cannot be imitated, so that it does not suffer so keenly from this unfair competition. The only way to adulterate comb honey is by the well-known process of feeding the bees with syrup, which is, of course, necessary at times, but should not otherwise be practiced, for the reason that it is costly at best, and impairs the quality of the product, to the detriment of the price.

LEADING HONEY PLANTS.

North Carolina is well supplied with native honey plants, especially in the eastern section. Three of the questions sent out by. the writer bear on this subject, and the answers give an excellent view of the matter for the entire State. Of course each bee-keeper may have his own preferences or prejudices as to which plant yields the best quality of honey, but the averages derived from a large number of replies are likely to be near the truth. We have been over all the reports, so as to reach some definite conclusions as to the order in which our principal honey plants should be ranked. 'Taking the State as a whole, sourwood, poplar (sometimes called tulip tree) and the clovers (all kinds) are the three leaders. As one of the main sources of honey, the sourwood is mentioned 167 times, to 162 for poplar, and 157 for the elovers. As to quality of honey, sourwood is mentioned 121 times, to 30 for poplar, and 65 for the clovers. For quantity of honey, the sourwood is mentioned 48 times, to 57 for poplar and 39 for the clovers. Of these three leaders the poplar is the most widely distributed, and is prominently mentioned in all sections, from east to west. The sourwood is principally confined to the piedmont section, though, reported also from the lower mountain localities and from the western border of the eastern region. The clovers are found in all parts, though more abundant in the mountain and piedmont sections. Next to these three we find the gallberry (Vaccinium sp.) and black-gum, both taking high rank and both found principally in the east. Persimmon ranks sixth and is reported chiefly from the. east, several mentioning it as irregular in yield and lasting but a short time, but doing well for the short period. The basswood, or linden, comes seventh and is reported only from the west. Holly and huckleberry (low and high) are next in order, both being in the east. Buckwheat follows and is confined to the west. Ironweed (so-called, really a species of aster), while reported almost entirely from the piedmont, and especially from Mecklenburg, Cabarrus and neighboring counties, taking relatively high rank both for quality and quantity of honey produced, grows over larger areas in the piedmont and 
eastern parts of the State, especially on the stiffer soils. Bringing together all these reports and tabulating them for more easy reference, we find that our twenty-four leading honey plants are as follows:

TWENTY-FoUR LEAdTNG BeE PASTURAgE PLANTS.

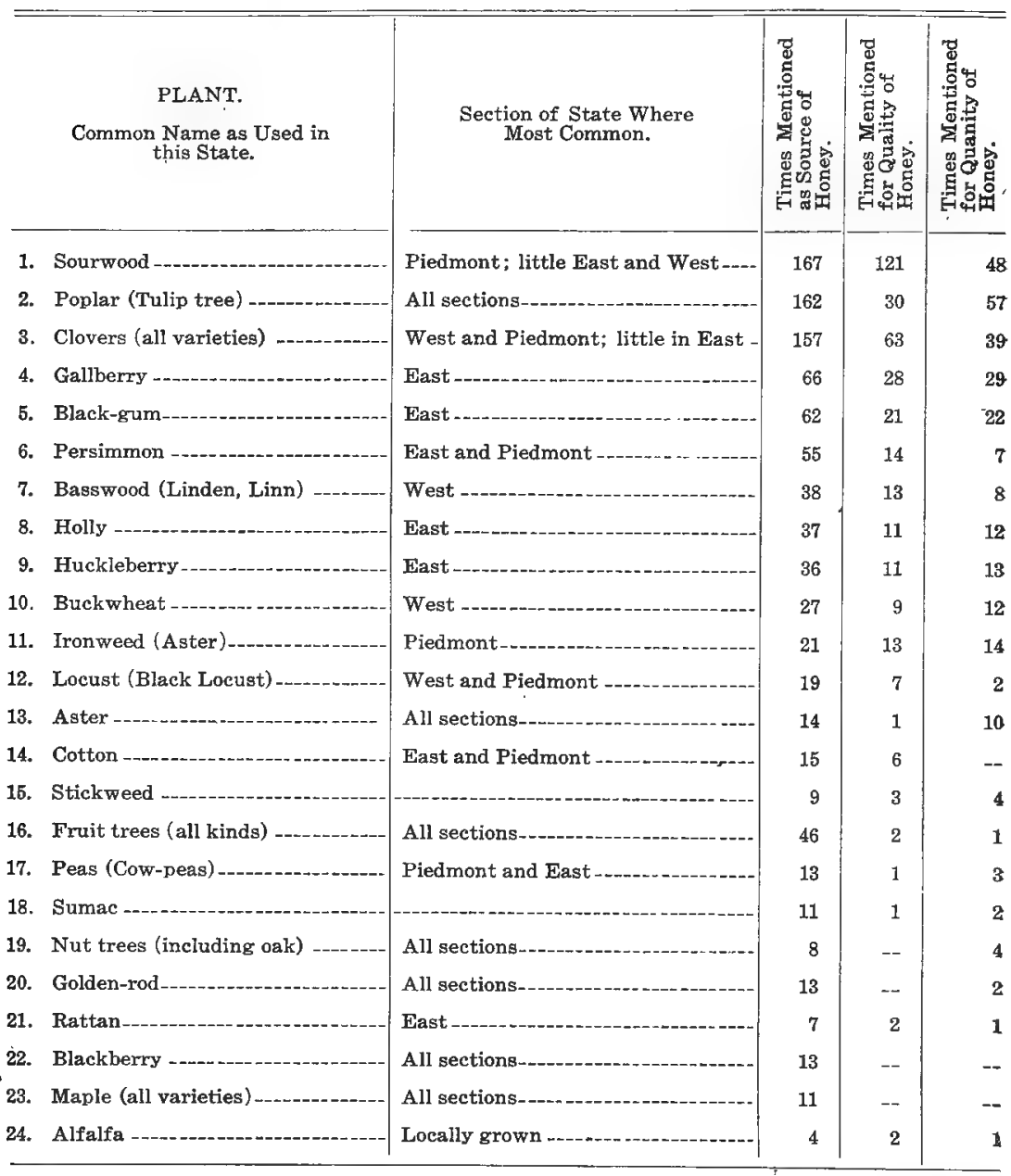

Botanical.-For the sake of technical accuracy we give herewith, so far as we can ascertain, the scientific names of our honey-plants, numbered to correspond to the above list. 1, Oxydendron arboreum; 2, Liriodendron tulipfera; 3, Trifolium sp.; 4, Ilex sp.; 5, Nyssa sp.; 6, Diospyros virginiana; 7, Tilia sp.; 8, Ilex opaca; 9, Vaccinium sp. and Gaylussacia sp.; 10, Polygonum fagopyrum; 11, 
Aster sp.; 12, Robinia pseudacacia; 13, Aster sp.; 14, Gossypium herbaceum; 15, Bidens sp.; 16, ...; 17, Vigna catjang; 18, Rhus sp.; 19, ... ; 20, Soldago sp.; 21, probably Berchemia scandens; 22, Rubus sp.; 23, Acer sp.; 24, Medicago sp.

Of the above-named plants it is probable that fruit trees, sumac, nut trees, golden-rod, blackberry, and maple are visited by the bees principally for the purpose of gathering pollen or to get honey merely for brood-rearing. A large number of other plants receive mention only a few times, indicating that they are worked by the bees only very little or under circumstances of need.

The first fourteen plants named (down to and including cotton) may be regarded as our real leaders in producing honey, and include the main dependence of our bee-keepers of all sections. Of these fourteen we find that the eastern section gets a full share of eight, the piedmont gets the benefit of eight, though the cotton does not grow throughout all the section, and clover, persimmon and ironweed are rather limited, and the western section has six. This showing gives the east a decided advantage, especially when we consider that several of the leading honey producers (gallberry, black-gum, and persimmon) are chiefly confined to the east. Tabulating these facts to show the plants with which each section is favored, we find these fourteen leading plants distributed as follows:

FOURTEEN LEADING HONEY PLANTS.

\begin{tabular}{|l|l|l|}
\hline \multicolumn{1}{|c|}{ Eastern Section. } & Piedmont Section. & \multicolumn{1}{|c|}{ Western Section. } \\
\cline { 3 - 3 } Poplar. & Sourwood. & Poplar. \\
Gallberry. & Poplar. & Clovers. \\
Black-gum. & Clovers (limited). & Basswood. \\
Persimmon. & Persimmon (limited). & Buckwheat (limited). \\
Holly (limited). & Ironweed (limited). & Locust. \\
Huckleberry. & Locust. & Aster. \\
Aster. & Aster. & \\
Cotton. & Cotton (limited). & \\
\hline
\end{tabular}

Here we see that, while the piedmont section has as many of these plants as the east, they are more limited, so that the east really takes the lead in abundance and variety of honey plants. While the mountain section has basswood and buckwheat peculiar to itself, the piedmont, with its famous sourwood, can still hold its own, at least in all the localities where this plant is found. 
TYPES OF HIVES. (SEE ILLUSTRATION ON FRONT OF BULLETIN).

In the studies under the headings "Races or Varieties of Bees" and "Prices for Honey" we have already referred to the matter of hives for bees, since it seemed in each case to be relevant to the subject under discussion. But here we wish to refer to the matter directly and by itself. A study of the reports shows that the old hollow-log "gums" are in much more common use in the east than in either the piedmont or the west, as shown by the following table:

TYPES OF HIVES, "GUMS," ETC., IN USE.

\begin{tabular}{|c|c|c|c|}
\hline Section of State. & $\begin{array}{l}\text { Number Per- } \\
\text { sons Using } \\
\text { Frame Hives, } \\
\text { Bought or } \\
\text { Homemade. }\end{array}$ & $\begin{array}{l}\text { Number } \\
\text { Persons Using } \\
\text { Old Log, } \\
\text { "Gums." }\end{array}$ & $\begin{array}{l}\text { Number Per- } \\
\text { sons Using } \\
\text { Plank Hives, } \\
\text { Boxes, etc., of } \\
\text { Crude Make. }\end{array}$ \\
\hline East - & $---\ldots 63 \ldots \ldots$ & $----40---$ & $----43--$ \\
\hline Piedmont & ...144-_-.-- & - & 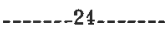 \\
\hline West---.- & 36 & - & - \\
\hline
\end{tabular}

The next step is to find out which of these types of hives actually brings in the most money to the bee-keeper. Since the east is the only section which uses enough of all three types of hives to render a fair judgment possible, we will confine our calculation to that section. It is a long calculation, but, when carefully compiled and put in tabulated form to show the average of yield, price, and total cash return from each type, we get the following:

RELATIVE RESULTS FROM DIFFERENT HIVES.

(Based on comb honey only, and only on data from eastern counties).

\begin{tabular}{l|l|c|c|c}
\hline \multicolumn{1}{c}{ Type of Hive. } & $\begin{array}{c}\text { Number } \\
\text { Reporting. }\end{array}$ & $\begin{array}{c}\text { Average } \\
\text { Yield. }\end{array}$ & $\begin{array}{c}\text { Average Price } \\
\text { Per Pound } \\
\text { in Cents. }\end{array}$ & Value. \\
\hline Log "Gums" & & & \\
Plank boxes, etc. & & \\
Frame hives
\end{tabular}

The majority of those who use the $\log$ "gums" either report the yield in gallons or do not know the yield, so that we were able to get the desired figures in only three instances. This is too small a number to give conclusive results, but, so far as they go, they show that the average yield of comb honey obtained from the "gums" is $131 / 3$ pounds; that it is worth a little less than 9 cents per pound, giving an average value of $\$ 1.11$ worth of honey per year for each log "gum." The roughly made square plank boxes-often with a re- 
movable cap on top-do better, yielding, according to sixteen reports, an average of $271 / 3$ pounds, worth a little less than 10 cents, making a value of $\$ 2.60$ per box. The frame hives, which have a super with movable frames, do much better yet, for an average of forty reports shows a yield of $371 / 2$ pounds, worth a little over 11 cents per pound, making a return of $\$ 4.13$ per hive. These figures speak emphatically, and, as between the crude plank box hives and the frame hives, the number of reports is large enough to render the record quite reliable. The log "gums" rank lowest in yield, and the honey brings the lowest price. The crude plank box hives yield twice as much, and the honey commands a better price, while the frame hives exceed the box hives by ten pounds in yield, and the honey commands a still higher price. Clearly it is a mistake for any one who keeps bees for profit to depend either on the "gums" or the plain boxes, for the difference in yield, accentuated by a difference in price, makes a very decided and striking difference in the value of the honey crop that is gathered and sold. The difference in price is based upon the fact that honey is regarded as a luxury rather than a necessity, and the consumer would rather pay a higher price for the sake of having it pure and in neat shape. Hence, the low price for honey from "gums," the higher price for honey from the rough plank boxes, and the best price for the honey that is made in the extracting frames in the "super" of a frame hive. And the very highest price of all is paid for it when in the little one-pound sections, which are a neat and handy table size, and especially if taken off as soon as the cells are filled and capped, before the combs are discolored.

It has already been pointed out, under the discussion of "Races or Varieties of Bees," that the three races most used in this State differ in their yield of honey, and it would be a very nice thing to figure out the exact difference for each race of bees in each kind of hive, but this is too fine a point for the records now in our hands to justify. Enough to know that on the whole the Italians do best, and that the bees of all races do best in the movable frame hives with super.

It is no part of the purpose of this BULLETIN to say that any one make of frame hive is better than others, nor is it even necessary in all cases for a bee-keeper to buy a complete stock of any of the patented hives. Many of our bee-keepers make their own hives and frames, and often they invent certain little modifications which render them different. from any and all other makes. It is always advisable for a bee-keeper who makes his own hives to have one standard model hive after which all others are made of precisely same dimensions so that frames or supers can be exchanged from one hive to another without difficulty. We venture to say that, if we could call 
together in one mass-meeting all the bee-keepers of this State and attempt to solve the question, Which is the best bee-hive for North Carolina bee-keepers? the meeting might stay in session for a month, with no satisfactory conclusion reached. Probably a dozen different hives would have good backing, with perhaps another dozen kinds developed by individual bee-keepers, each, of course, claiming certain advantages for his own bive. But the point is this - that the bees do better in the frame hives, where they store the honey in a super with frames or pound sections, and it is money in your pocket to get your swarms into that kind of a hive. The actual yield in pounds is greater from such hives, so that the rule holds good that the frame hives should be used, whether you sell the honey in the comb or extracted. (See the illustration on front cover of this Buluetin, and the explanation below it).

\section{BEE-MOTH AND- OTHER ENEMTES.}

The question on this subject was intended to show (when considered in connection with the questions regarding the race of bees

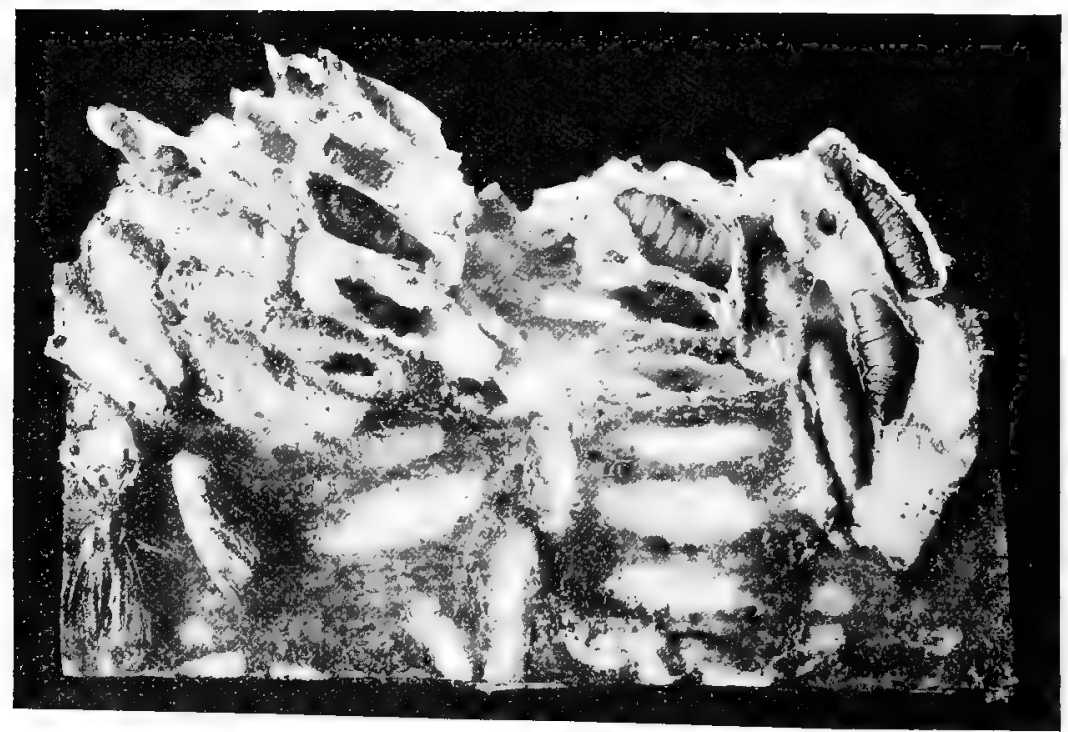

FrG. 4.-Showing different stages of the Bee-moth, and the webs which the larvæ make in the hive. Two of the adult insects are shown in the lower left-hand corner. (Photo by Prof. Hutt).

kept and the hives used) just what enemies are most serious and under what circumstances they are most destructive, so that we might from these facts reach some conclusion as to avoiding or 
reducing the damage. All told, tweive different enemies were mentioned, as follows:

Number

Reports.

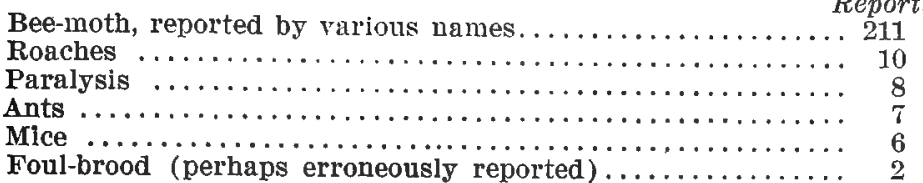

Also, "worthless bees," "robbers," "birds," "toads," "dysentery," and "picklebrood" were each reported once.

From this it appears that bee-moth is the one really important and formidable enemy, the others being relatively unimportant or easily controlled, although the possibilities of damage by such epidemics as paralysis, dysentery, and foul-brood (if this disease is really present in this State) are very. great. So far as we know nothing is now positively known concerning foul-brood or other brood-diseases in this State. If they do exist it is of great importance that they be discovered at once, and the extent of their spread ascertained. Bee-keepers who suspect the presence of these diseases should correspond with Dr. E. F. Phillips, Bureau Entomology, U. S. Department Agriculture, Washington, D. C. But we will omit detailed discussion of the other troubles in order to do full justice to a discussion of the bee-moth.

The bee-moth is so familiar to bee-keepers as to make any introduction or description unnecessary. While most bee-keepers know it familiarly by its proper name of bee-moth, yet a number reported it under other names, such as "worms," "moth," web-worm," "weevil," "bee-worms," "fly," etc. Going carefully over all the reports of this pest, and tabulating them in connection with the race of bees kept and the type of hive used, we find that we must drop a large number because they fail to answer one or another of these questions, or, in cases where they use several types of hives, it is not possible to tell which is most to blame. Leaving out all these doubtful or incomplete records, and confining ourselves strictly to clear and positive reports (of which we have enough to make our conclusions safe), we get the following result:

BEE-MOTH AS AFFECTING DIFFERENT RACES OF BEES IN DIFFERENT KINDS OF HIVES.

\begin{tabular}{|c|c|c|}
\hline Race of Bees and Hives. & $\begin{array}{c}\text { Number } \\
\text { Reporting } \\
\text { Serious } \\
\text { Damage. }\end{array}$ & $\begin{array}{c}\text { Number Re- } \\
\text { porting Slight } \\
\text { or No } \\
\text { Damage. }\end{array}$ \\
\hline Italians, in frame hives & 31 & 37 \\
\hline Hybrids, in frame hives- & 42 & 22 \\
\hline Blacks, in frame hives & 23 & 8 \\
\hline Blacks, in plank boxes, etc. ---- & 17 & 3 \\
\hline Blacks, in log "gums" - & 20 & 1 \\
\hline
\end{tabular}


In the case of all three races of bees the bee-moth is much less destructive in the frame hives than in either boxes or log "gums"; also, it is less destructive in the boxes than in the gums, though it is only in case of the Blacks that we have enough reports to thoroughly establish the fact. A study of the table shows clearly and convincingly that Italian' bees in the frame hives are least hurt by the bee-moth; Hybrids in frame hives are hurt more, while the Blacks (in the frame hives) suffer much more than either of the others. With the Blacks we carry the study further and find that they suffer worse in the plank-box hives than in the frame hives, while the ones who suffer most of all are the Blacks in the log "gums." We have seen in our studies under "Races of Bees" that the Italians produce the most honey, the Hybrids second, and the Blacks third; and here we find that, with regard to resistance to beemoth, they take the same rank. We also found in our study of "Types of Hives" that the frame hives rank first in value of honey yield, the plank-box hives second, and the log "gums" last; and here we find that, with regard to resistance to bee-moth, they take the same rank. Nothing is plainer than that the best combination, both for profits and for resistance to bee-moth, is to keep Italian bees in frame hives. It is equally plain that the poorest combination, both with regard to profits and bee-moth, is to keep the common Black bees in log "gums."

It is plain, from the tables and discussion just preceding, that Italian bees in the frame hives are the least subject to the ravages of the bee-moth; but there are other very important factors not included in our questions which were repeatedly stated by beekeepers in their replies. Most important among these is the fact that strong colonies, with vigorous queens and a full number of workers, are not usually much troubled; but if the colony becomes weak or depleted from any cause, the bee-moth is likely to gain a foothold and keep the colony weak until it may kill out the swarm entirely. Freezing, long rainy spells, poor honey flow, being queenless for a time, too severe robbing-all these things tend to deplete the colony so that the bee-moth takes possession. Most of our keen, active bee-keepers are fully aware of these facts, but every now and again we receive a mournful complaint from some one who is much worried by the bee-moth, when, likely as not, he is keeping the Black bees in old log "gums," the very conditions which enable the beemoth to do its greatest destruction.

In order to furtber emphasize the points brought out in reference to the injury by bee-moth, and the methods of avoiding it, we quote from the reports of several of our North Carolina bee-keepers on the 
subject. Over thirty persons made just such remarks as these, and they fit the case exactly and give a good idea of the facts:

"Weak colonies troubled with bee-moth."

"Bee-moth; lost six or seven weak colonies."

"Bee-moth, in bad seasons."

"Bee-moth, when they lose the queens."

"Sometimes bothered with moth during winter."

"No moths if kept strong."

"Bee-moth bad in wet seasons."

"No trouble unless bees get weak."

"Bee-moth, but Italians are free if kept strong."

"Bee-moth in log gums, but not in hives."

"Bee-moth, after robbing.

"Weak bees killed out; strong ones no trouble."

The final advice with regard to bee-moth is, get Italians, keep them in frame hives, and use every effort to keep the colony populous and strong.

\section{BEE-KEEPING JOURNALS.}

The last question on the list which we sent out related to journals or papers devoted especially to bee-keeping. A number mentioned that they secured information concerning bees from their farm papers, and several mentioned one or more books which they have on the subject. Out of about 340 persons who answered the question at all, 118 take one or more bee-keeping journals. Considering the fact that all of these people have at least ten colonies of bees, it seems to us that the number who are subscribers is smaller than it should be. Here, again, as with regard to hives for bees, it is a delicate matter to recommend any one above others; but, since our bee-keepers should at least be given an opportunity to know what the journals are, we give below some convenient information regarding each of the bee-keeping journals which are taken by our bee-keepers.

"Gleanings in Bee Culture" is published every two weeks bo The A. T. Root Co., Medina, Ohio; $\$ 1$ per year.

"American Bee Journal" is published monthly at $\$ 1$ per year. Address 118 W. Jackson, Chicago, Ill.

"American Bee-keeper" is published monthly at Falconer, N. Y. Subscription, 50 cents per year ; 3 years for $\$ 1$.

"Bee-keeper's Review" is published monthly at Flint, Mich; $\$ 1$ per year.

SUMMARY OF BEE-KEEPING IN THE STATE.

North Carolina is well adapted to bee-keeping, but the industry has not been well developed along the best lines. Each of the three great sections (east, piedmont, and west) has certain splendid honey plants. Our bee-keepers, especially in the east, have relied too much 
on the wild Black bees, and have not been so particular about the introduction of Italians as would have been best. We are also too prone to use the old log "gum" or crude plank box hive instead of the modern frame hives. In consequence of these facts our yield of honey is smaller than need be, the price received is lower than should be, and the colonies are more easily destroyed by bee-moth than should be. These difficulties will disappear or be gradually overcome with a little closer attention to the details and fine points of the business and with more general reading and study along these lines. Whether the bee-keeper sells comb honey or extracted honey, his best interests.uill be served if he will Italianize his swarms, keep them in hives with movable frames, and keep them in strong condition.

\section{WHAT ENCOURAGEMENT CAN BE GIVEN THE INDUSTRY?}

The writer is not a bee-keeper and does not claim to be able to advise in bee-keeping matters, except in such general matters as are discussed in this BULletin. Indeed, he knows nothing about the business, except what he has learned in conducting this inquiry and in averaging and tabulating the results. When we began this work several bee-keepers at once expressed satisfaction that an effort was being made by our Department to aid the bee-keepers, and from time to time inquiries have come, which we have answered as best we could. Fortunately, most of these rere about the bee-moth, the remedies for which are well known. But the bee-keeping industry never has been, and is not now, sufficiently well organized, or suffciently important, or, at least, has not made itself sufficiently felt, to bring about the employment of a skilled and experienced man to especially aid and protect the industry; and until the industry can successfully do away with these obstacles, the employment of such a man is not probable.

Recently the State Department of Agriculture has added to its staff of workers MLr. T. B. Parker, well known to the farmers of the State. Mr. Parker has in the past been a practical bee-keeper, and at the time was an exceptionally close student of bee-keeping matters. Although he is now employed for other lines of work, our bee-keepers can in future benefit by his knowledge when they send inquiries to us. We realize that this is not providing as fully and as satisfactorily for the bee-keepers as we should like, but it is the best that can be done in the present state of the industry.

The United States Department of Agriculture at Washington has recently increased its worls in apiculture, and our bee-keepers can at all times feel free to call on that Department for reasonable advice or for publications on this subject. The man in charge of this work is Dr. E. F. Phillips, Apiculturist, Bureau of Entomology, U. S. Department of Agriculture, Washington, D. C. 
Several bee-keepers have suggested that a State bee-keepers' association should be organized. If there is a large enough number of bee-keepers who are deeply enough interested to actually go down in their pockets to pay dues, to buy tickets, pay hotel bills, etc., to the extent of a few dollars each year, so as to maintain such an organization and attend its meetings, then there can be no doubt that it could succeed and could eventually be a powerful factor in developing a large and profitable honey industry. But it is to be remembered that no matter where a meeting is held, it would be a long distance from some of the members, and some plan of holding the meetings in different places from year to year would be necessary. Te give in the last pages of this BuLletin a list of all bee-keepers in the State known to us who have fifty or more colonies of bees. If there is a real sentiment for a State bee-keepers' association these bee-keepers will be able to find it out among themselves. The writer stands ready to assist and encourage in any reasonable way, will give further lists of bee-keepers known to us, etc., but we cannot undertake to work up the sentiment and bring the organization into being; that is for the bee-keepers themselves. So many efforts at organization either fail utterly or are only partially successful that our bee-keepers should think carefully before attempting to form an organization. There is plenty of good work for such an organization to do, provided it has two essentials-numbers and enthusiasmthe real enthusiasm that is willing to pay something in cash even without hope of actually getting it back again, but for the purpose of furthering a worthy industry in the State.

\section{LEADING BEE-KEEPERS OF THE STATE.}

We give below a list of all the bee-keepers of whom we have record who have as many as fifty or more colonies of bees. There are no doubt a good many others, for, as was pointed out in the beginning of this Bulletin, our records must be far from complete; but we feel that this list should be of some interest and use. Records of all the rest of the 360 bee-keepers (all having ten colonies or more) who have furnished information to us are in this office, available for any proper use, but it does not seem desirable to publish them all here. 
LEADING BEE-KEEPERS OF THE STATE.

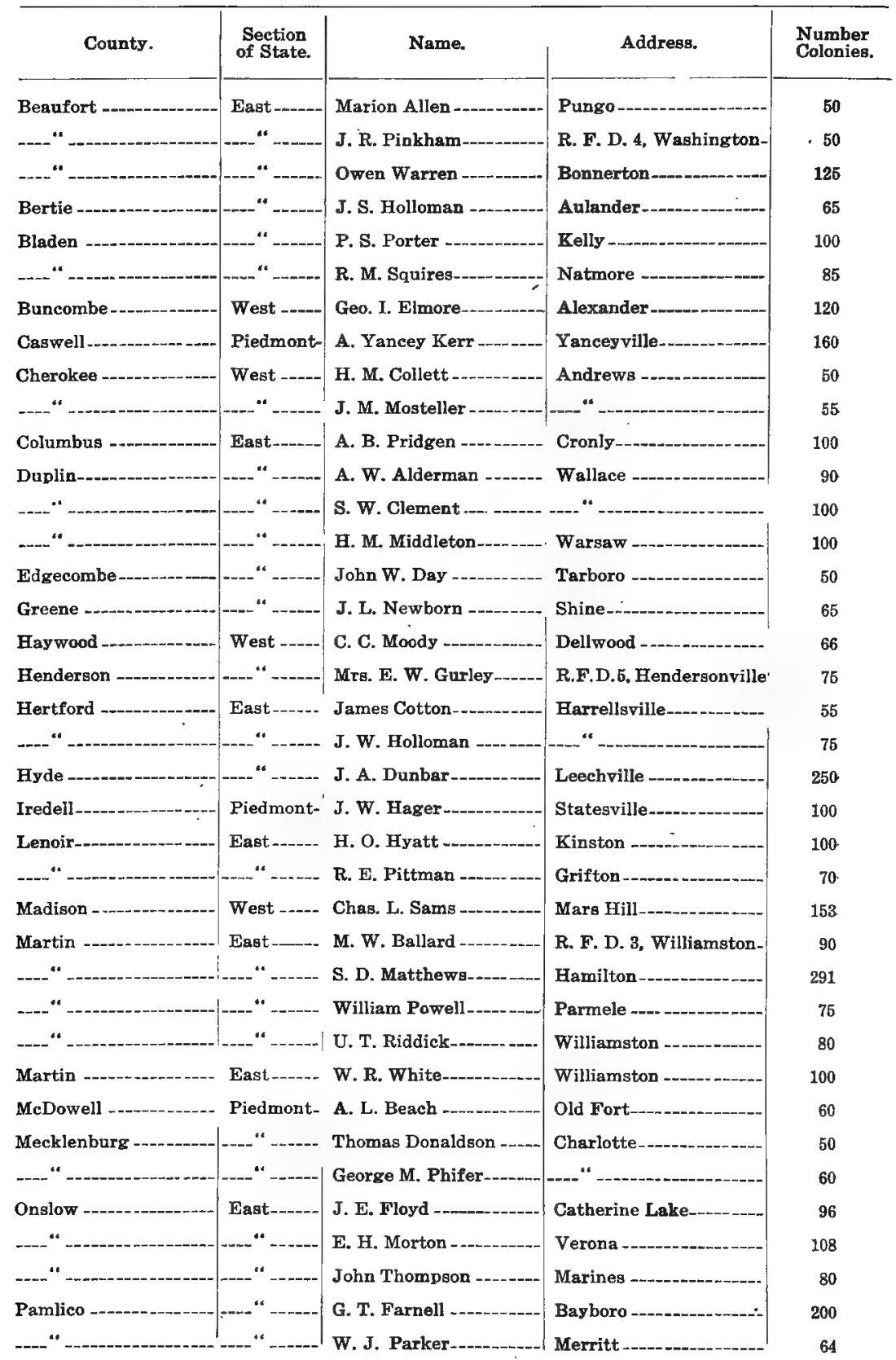


LEADING BEE-KEEPFRS OF THE STATE-continued.

\begin{tabular}{|c|c|c|c|c|}
\hline County. & $\begin{array}{l}\text { Section } \\
\text { of State. }\end{array}$ & Name. & Address. & $\begin{array}{l}\text { Number } \\
\text { Colonies. }\end{array}$ \\
\hline Pámlico -.-- & Fast--....- & W. P. Robinson -...... & Oriental & 60 \\
\hline Pender -----.. & ....“ - & D. G. Kelly & Canetuck ------_-_-_-_- & 75 \\
\hline Robeson -..- & ----" ----- & W. P. Burns & Maxton-_- & 50 \\
\hline ----“"--- & --_“ ----. & J. W. Faircloth- & Rowland____. & 50 \\
\hline$\ldots$ & ...." ------ & N. W. Goddy & R. F. D. 3, Rowland -- & 75 \\
\hline Sampson -.--- & -.." - - & W. R. McBride - & R. F. D. 2, Parkersburg & 65 \\
\hline Scotland--. & ----“ ------ & Wm. Carmichael ...-... & Johns Station -........ & 50 \\
\hline Surry ----- & Piedmont- & Miss Ella Greenwood & Mount Airy & 65 \\
\hline Wake--.-- & - & W. L. Womble & Raleigh---.- & 100 \\
\hline Warren -..-. & --_.“ & W. H.Pridgen -- & Creek-_-_-- & 80 \\
\hline Washington - & East.-...--- & Grisbourne V. Lewis & Roper --- & 100 \\
\hline ---“" ------ & -_-_“ --...-. & B. R. Marriner -- & -..-“ ---_... & 100 \\
\hline --_“ -- & ---" ---.. & T. T. Woodley & Cherry - & 100 \\
\hline Watauga & West -...- & H. A. Davis -... & R. F. D. 1, Moretz & 50 \\
\hline --."“ --... & -...“ “-..-- & A. J. MeBride & Mast................ & 50 \\
\hline Yadkin -.. & Piedmont- & Mrs. Emma Shugart-_- & Jonesville -------. & 194 \\
\hline
\end{tabular}




\section{REPORT FROM LEAF TOBACCO WAREHOUSES FOR MONTH OF DECEMBER, 1907.}

Pounds sold for producers, first hand . . . . . . . . . . . .

Pounds sold for dealers. ....................... 428,175

Pounds resold for warehouse....................... 641,950

Pounds resold for other warehouses.................. 13,977

Total............................. 13,646,699

\section{REPORT FROM LEAF TOBACCO WAREHOUSES FOR MONTH OF JANUARY, 1908.}

Pounds sold for producers, first hand. . . . . . . .

Pounds sold for dealers.......................... 399,800

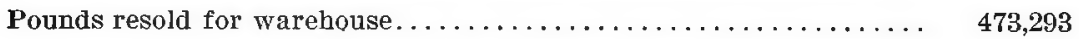

Pounds resold for other warehouses................ 14,353

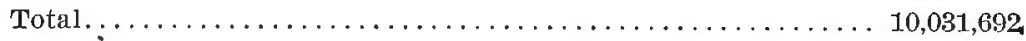


Cornell University Library

Bee-keeping in North Carolina, A study of

I...

3 1924003421900 
